Universal Decimal Classification (UDC) number 613.634

\title{
THE SUBSTANTIATION OF A BENCHMARK LEVEL FOR VANADIUM IN HUMAN BIOMEDIA (BLOOD)
}

\author{
M.A. Zemlyanova ${ }^{1}$, T.S.Ulanova ${ }^{1}$, O.O. Sinitsyna ${ }^{2}$, O.V. Gileva ${ }^{1}$ \\ ${ }^{1}$ FBSI «Federal Scientific Center for Medical and Preventive Health Risk Management Technologies», 82 \\ Monastyrskaya St, Perm, 614045, Russia, \\ ${ }^{2}$ Federal State Budget Institution «A.N. Sysin Research Institute of Human Ecology and Environmental \\ Health», Russian Federation, Moscow, 10 Pogodinskaya St., Building 1, 119992
}

\begin{abstract}
The study presents a comprehensive hygienic assessment of environmental objects located in the zone influenced by ferrovanadium production; the results of chemical analysis and laboratory investigations of biological fluids (blood) of people living in different areas of exposure; correlation dependencies for the "dose blood concentration of vanadium" and the "exposure marker - effect marker" relationships. Based on the results of epidemiological studies the responses of the organism to chronic exposure of exogenous vanadium are substantiated, and the benchmark vanadium blood level is determined.
\end{abstract}

Key words: vanadium, blood, benchmark level, epidemiological studies.

Modern negative trends in changes in population health parameters are determined by the complex of factors of the human environment. [7] Especially these changes are attributable to company towns dependent on enterprises [5]. The greatest risk to the health of the urban population, especially in the cities with steel production, is related to heavy metals of the first class of hazard, which among others includes vanadium.

According to an annual report on "The State and Protection of the Environment in the Perm Krai in 2011," Chusovoy city of Perm Krai has the fourth leading position among the municipalities of the region in regard to its anthropogenic load. The main source of atmospheric air pollution in Chusovoy is a city-forming enterprise - "Chusovoy Metallurgical Works" JointStock Company (OAO), which is the Europe's largest manufacturer of ferrovanadium alloys that annually emits over 12 tons of vanadium pentoxide [16].

Hygienic assessment of the results of monitoring and field studies of ambient air quality in Chusovoy indicate the exceeding (up to 6 times) of the reference level during chronic inhalation exposure to vanadium pentoxide, characterized by the directed toxic effects on the respiratory system. To confirm the danger of respiratory disease development caused by bad air quality in regard to the content of vanadium pentoxide, relevant is to justify the benchmark levels of vanadium in the blood.

The investigation and assessment of the vanadium content in the objects of the environment at the reference concentration level and below, as well as in human biosubstrates, can be implemented only in the presence of a modern highly sensitive and selective method of determination. Optimal for these tasks is the method of mass spectrometry with inductively 
coupled plasma, based on which a complex of quantitative methods for determination of vanadium in the ambient air and in human blood has been developed [2, 12].

The aim of the present study is to substantiate the benchmark vanadium level in human biological media (blood) under conditions of chronic inhalation exposure.

Materials and methods. Complex of sanitary and hygienic, epidemiological and statistical methods, mathematical methods for calculating the distribution of vanadium pentoxide in the ambient air from the sources of the studied manufacture, and methods for calculating the exposure and odds ratio were used. The causality modelling was carried out. Investigations were carried out on the areas with different levels of air and drinking water pollution with vanadium resulting from emissions and discharges of ferrovanadium alloys production. Based on the results of calculations of vanadium pentoxide dispersion in the ambient air, which were verified using field observation data for the period of 2010-2011, and calculations of the total average daily dose by chronic exposure, 9 exposure zones (monitoring zones) were identified that were located at a distance of 0.2 to $10 \mathrm{~km}$ from the source of pollution of environmental objects. The zone with the lowest vanadium exposure was chosen as the control.

Methods of chemical-analytical control were applied to determine vanadium content in the ambient air (in equivalent of vanadium pentoxide) [11], in drinking water and in blood of the exhibited population [2]. The blood was chosen as a biosubstrate for the quantitative assessment of the toxicant content due to the fact that the concentration of elements in the blood has a higher correlation with the absorbed dose compared with other body fluids and therefore most adequately represents the exposure [13]. Furthermore, the concentration of metals, including vanadium, in the blood is a marker of chronic exposure to metals [19].

The quantitative determination of vanadium in the objects of human environment and in human blood was carried out using a mass spectrometer Agilent 7500cx (Agilent Technologies, USA). Determination of vanadium in the ambient air was carried out in accordance with the Methodological Guidelines MUK 4.1.2953 - 11 [12], a range of determinations 0.000005-50.0 $\mathrm{mg} / \mathrm{m}^{3}$. The determination of vanadium in the blood was carried out with Octopol/reaction cell, where helium was used as the cell gas. [17] Control of the results of blood analysis was carried out by using a reference material with a similar matrix structure; for this purpose standard blood samples were used in various concentration ranges, SERONORM L1-L3 (Norway).

For in-depth study a sample of 950 children in the age of 4 to 7 years (150 persons from each exposure zone, including boys - 51.6\%, girls - 48.4\%) living under vanadium exposure during at least 1 year, was formed. The sample included individuals with equal ethnicity and race, and weight and height parameters, not exceeding the $\pm 15 \%$ limits of the Quetelet weight- 
height index. The children did not take any drugs which could have a pronounced effect on hemodynamics, liver function, etc. (such as barbiturates, omeprazole, cimetidine, etc.), within 30 days before the study entry. According to the social welfare criteria the sample of children had the average level of material security, and their housing conditions met hygienic standards. Biomedical research were carried out in accordance with the strict observance of ethical guidelines for biomedical research outlined in the Declaration of Helsinki in 1975 as revised in 1983, and with the national standard of Russian Federation GOST-R 52379-2005.

Analysis of immunological (immunoglobulin A, M, E total immunoglobulin G specific to vanadium, phagocytosis) and biochemical parameters (ALT, AST, total protein), which characterize the development of adverse effects after intake of vanadium via inhalation and oral route (with drinking water) [10], was performed using standardized methods [8].

According to laboratory abnormalities with the reference to the physiologically normal values at various levels of the vanadium content in the blood [17], assessment of organism responses to chronic exposure of vanadium was carried out. To confirm the adequacy of using vanadium concentration in the blood as a criterion of chronic exposure, the relationship between the average vanadium concentration in the blood and the average annual vanadium concentration (in equivalent of vanadium pentoxide) in the ambient air of the exposure areas of interest during the same period of observation was determined.

Substantiation of the effect markers was made based on determination and assessment of the relationship between the deviations of the investigated laboratory parameters from the physiological norm and the concentration of vanadium in the blood. For this purpose, a multistage calculation of odds ratios (OR) was applied [17]. Based on the odds ratio (OR) the presence and strength of this relationship was assessed. As a criterion of the relationship the condition of $\mathrm{OR} \geqslant 1$ was accepted.

Assessment of parameters of the relationship of the odds ratio for laboratory abnormalities in children of the exposed population relative to the control group was performed by constructing a regression model in the form of an exponential function:

OR - ea0 - a1 $x$, where OR is the odds ratio, $x$ is the average annual vanadium concentration in the blood in children, $\mathrm{mg} / \mathrm{dm} 3, \mathrm{a} 0$, a1 are model parameters determined by the regression analysis method. The adequacy of the model was verified using analysis of variance with Fisher's exact test [4]. The differences were considered statistically significant by $\mathrm{p} \leqslant 0.05[2]$.

When determining the benchmark level, confidence limits of the model were taken into account, which allow obtaining 95\% interval assessments. The value corresponding to the 
upper limit of the $95 \%$-confidence interval of the resulting model was taken as a benchmark concentration [11].

Results and discussion. According to dispersion calculations and the own field measurements for the study period (2010-2011) the ambient air in the studied area where ferrovanadium production plant is located, the average annual concentration of vanadium (in equivalent of vanadium pentoxide) ranged from $1.97 \cdot 10-5$ to $42.2 \cdot 10-5 \mathrm{mg} / \mathrm{m} 3$.

The obtained range of average annual concentrations was 0.01 to $0.21 \times$ Average daily maximum permissible concentration according to the hygienic standard GN 2.1.6.1338-03 [4] or from $0.28 \mathrm{RfCcr}$ (reference concentration by chronic inhalation exposure) to $6.04 \mathrm{RfCcr}$ according to the Guideline 2.1.10.1920-04 [14] (Table 1). In the ambient air of the control zone the average annual vanadium concentration was $0.19 \cdot 10-5 \mathrm{mg} / \mathrm{m} 3$ which corresponds to $0.001 \times$ Average daily maximum permissible concentration or $0.03 \mathrm{RfCcr}$.

In water from the centralized drinking water supply of the studied exposure zones, vanadium concentration ranged from $0.4 \cdot 10-5$ to $5.0 \cdot 10-5 \mathrm{mg} / \mathrm{dm} 3$ that corresponded to 0.00004 to $0,0005 \times$ Maximum permissible concentration according to SanPiN (Sanitary Regulations and Standards) 2.1.4.1074-01 [15] or 0.000003 to 0,00004 RfDcr according to the Guideline 2.1.10.1920-04 [14]. In drinking water of the control zone the average annual vanadium concentration was $0.1 \cdot 10-5 \mathrm{mg} / \mathrm{dm} 3$ that corresponds to $0.00001 \times$ Maximum permissible concentration or 0.000001 RfDcr.

Quantitative assessment of chronic vanadium exposure though inhalation and oral (with drinking water) routes of exposure of children in the studied sample showed that the total average daily dose of vanadium under conditions of annual exposure amounted to 2,5・10-5 $5,0 \bullet 10-4 \mathrm{mg} /(\mathrm{kg} \cdot \mathrm{day})$. Contribution of aerogenic factor to the total mean daily dose of vanadium was 94.2 to $99.8 \%$. In the control area, the total average daily dose of vanadium during the year was $2.0 \cdot 10-7 \mathrm{mg} /(\mathrm{kg} \bullet$ day $)$. The priority critical organs with the inhalation routes of vanadium entry are respiratory organs (sensitization); by the oral route - the liver and gastrointestinal tract [14].

The exposure assessment results obtained are consistent with those of the previous studies $[1,9,19,20]$, in which the authors as the main route of vanadium pentoxide entry in humans indicate inhalation of vapours and aerosols contained in the ambient air. The annual average concentration of vanadium in the blood of children from exposure zones ranged from 0.00054 to $0.009 \mathrm{mg} / \mathrm{dm} 3$, which corresponds to 0.62 to $10.3 \mathrm{RL}$ (Table 3 ). In children of the control zone vanadium concentration in the blood was $0.00012 \mathrm{mg} / \mathrm{dm} 3$, which corresponds to 0.14 RL [15] (Table 2). 


\section{Average annual vanadium concentration in the ambient air (in equivalent of vanadium pentoxide)}

\begin{tabular}{|c|c|c|c|c|}
\hline \multirow[b]{2}{*}{$\begin{array}{l}\text { Zone of } \\
\text { exposure }\end{array}$} & \multicolumn{2}{|l|}{ Ambient air } & \multicolumn{2}{|c|}{ Drinking water } \\
\hline & $\begin{array}{c}\text { Average annual } \\
\text { concentration, } \mathrm{mg} / \mathrm{m}^{3} \\
(M \pm m)\end{array}$ & $H Q$ & $\begin{array}{c}\text { Average annual } \\
\text { concentration, } \mathrm{mg} / \mathrm{dm}^{3} \\
\qquad(M \pm m)\end{array}$ & $\begin{array}{l}\text { Proportion of the } \\
\text { Maximum } \\
\text { permissible } \\
\text { concentration } \\
\left(0.1 \mathrm{mg} / \mathrm{dm}^{3}\right)\end{array}$ \\
\hline 1 (control) & $0,19 \cdot 10^{-5_{ \pm 0,05} \cdot 10^{-5}}$ & 0,027 & $0,2 \cdot 10^{-5} \pm 0,02 \cdot 10^{-5}$ & 0,00002 \\
\hline 2 & $1,97 \cdot 10^{-5_{ \pm 0,51} \cdot 10^{-5}}$ & 0,281 & $0,4 \cdot 10^{-5} \pm 0,01 \cdot 10^{-5}$ & 0,00004 \\
\hline 3 & $2,41 \cdot 10^{-5} \pm 0,39 \cdot 10^{-5}$ & 0,344 & $0,6 \cdot 10^{-5_{ \pm}} 0,03 \cdot 10^{-5}$ & 0,00006 \\
\hline 4 & $3,08 \cdot 10^{-5_{ \pm 0}}, 71 \cdot 10^{-5}$ & 0,440 & $4,0 \cdot 10^{-5_{ \pm 1,0}} \cdot 10^{-5}$ & 0,0004 \\
\hline 5 & $4,06 \cdot 10^{-5} \pm 0,26 \cdot 10^{-5}$ & 0,579 & $3,0 \cdot 10^{-5_{ \pm 0,8}} \cdot 10^{-5}$ & 0,0003 \\
\hline 6 & $6,11 \cdot 10^{-5} \pm 0,48 \cdot 10^{-5}$ & 0,770 & $3,0 \cdot 10^{-5} \pm 0,7 \cdot 10^{-5}$ & 0,0003 \\
\hline 7 & $15,86 \cdot 10^{-5_{ \pm}} \pm 1,73 \cdot 10^{-5}$ & 2,266 & $2,0 \cdot 10^{-5_{ \pm 0,4}} \cdot 10^{-5}$ & 0,0002 \\
\hline 8 & $24,12 \cdot 10^{-5} \pm 2,46 \cdot 10^{-5}$ & 3,445 & $1,0 \cdot 10^{-5} \pm 0,3 \cdot 10^{-5}$ & 0,0001 \\
\hline 9 & $42,27 \cdot 10^{-5} \pm 3,83 \cdot 10^{-5}$ & 6,039 & $5,0 \cdot 10^{-5} \pm 0,2 \cdot 10^{-5}$ & 0,0005 \\
\hline
\end{tabular}

The average annual vanadium concentration in the blood of children is a marker of chronic vanadium exposure, as is confirmed by the significant direct correlation $(r=0.75$, $\mathrm{p}=0.0005$ ) between the average annual concentration of vanadium in the blood with the average annual concentration of vanadium in the ambient air in the areas of interest (during the same period of observation) (see Figure). The mathematical model describing this relationship, is described by the following linear equation: $\mathrm{y}=0.00078 \mathrm{x}+21.95$, where $-\mathrm{y}$ is the concentration of vanadium in the blood, $\mathrm{mg} / \mathrm{dm} 3, \mathrm{x}$ is the concentration of vanadium in the air, $\mathrm{mg} / \mathrm{m} 3$.

As a result of investigations and assessment of the parameters of the relationship between the odds ratio for laboratory abnormalities in exposed children and vanadium concentration in the blood, the following effect markers were identified: increased vanadiumspecific IgG, increased total IgE, increased AsAT activity, decreased total protein, decreased serum IgA, decreased phagocytic blood (Table 3).

Calculation of the no-observed effect concentration (benchmark concentration) of vanadium in the blood for each marker of the effect yielded several upper limits of the $95 \%$ confidence interval for the benchmark average annual concentrations of vanadium in the blood (Table 4).

A comparison of the values of the upper limit of the $95 \%$ confidence interval for vanadium levels in the blood in the markers of effects obtained, demonstrated that the limiting 
index of hazard was an increase in IgG specific to serum vanadium, the benchmark level for which was $0.0023 \mathrm{mg} / \mathrm{dm} 3$.

Using this index as a limiting hazard measure under conditions of high content of vanadium in the blood, is pathogenetically substantiated, since vanadium entry in the bronchial tree and its interaction with the receptors of alveolar macrophages in the epithelium of bronchi and alveoli leads to synthesis of specific immunocompetent proteins (IL-4, IL-6, IL-10) and formation of a pool of $\mathrm{T}$ cells (memory cells) which support the production (via B cells) of immunoglobulin (IgG) specific to vanadium [6]. Therefore, assessment of specific sensitization to vanadium based on increase in IgG is an immunological criterion of chemical sensitization to vanadium under conditions of exposure to vanadium.

Conclusions. The proposed methodological approach allowed substantiation of the benchmark vanadium level in the blood, which amounted to $0.0023 \mathrm{mg} / \mathrm{dm} 3$. The most sensitive indicator of the organism's response to vanadium exposure is an increase in $\operatorname{IgG}$ specific to vanadium. This concentration of vanadium in the blood under conditions of complex chronic exposure to vanadium can be recommended as safe and associated with an acceptable health risk.

Table 2

Vanadium concentration in the blood of children in the zones of exposure

\begin{tabular}{|c|c|c|c|c|}
\hline \multirow{2}{*}{$\begin{array}{l}\text { Zone of } \\
\text { exposure }\end{array}$} & \multicolumn{3}{|c|}{ Concentration, $\mathrm{mg} / \mathrm{dm} 3$} & \multirow{2}{*}{$\begin{array}{l}\text { Proportion of the upper bound of the reference } \\
\text { limit in the blood } \\
(\mathrm{RL}=0.00006-0.00087 \mathrm{mg} / \mathrm{dm} 3)\end{array}$} \\
\hline & mean $(\mathrm{M} \pm \mathrm{m})$ & minimum & maximum & \\
\hline 1 (control) & $0.00042 \pm 0.00008$ & 0.000042 & 0.000501 & 0.48 \\
\hline 2 & $0.00054 \pm 0.00004$ & 0.000321 & 0.000763 & 0.62 \\
\hline 3 & $0.00061 \pm 0.00011$ & 0.000395 & 0.000875 & 0.70 \\
\hline 4 & $0.00097 \pm 0.00018$ & 0.000655 & 0.001121 & 1.12 \\
\hline 5 & $0.00268 \pm 0.00035$ & 0.000951 & 0.003271 & 3.08 \\
\hline 6 & $0.00307 \pm 0.00028$ & 0.001151 & 0.005972 & 3.52 \\
\hline 7 & $0.00398 \pm 0.00044$ & 0.002734 & 0.007424 & 4.57 \\
\hline 8 & $0.00805 \pm 0.00015$ & 0.006541 & 0.01245 & 9.25 \\
\hline 9 & $0.00900 \pm 0.00022$ & 0.00701 & 0.01366 & 10.3 \\
\hline
\end{tabular}

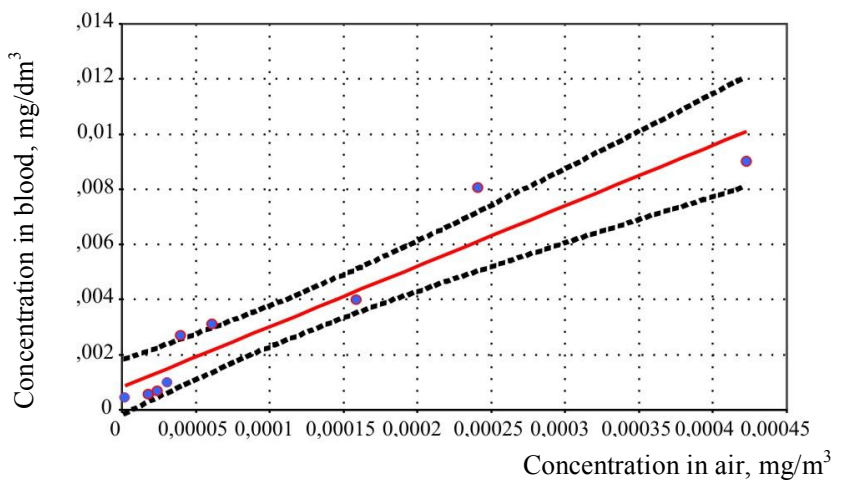


Figure. Relationship between the average concentration of vanadium in the blood of children and the average annual concentration of vanadium (in equivalent of vanadium pentoxide) in the ambient air in exposure zones

Table 3

\section{Parameters of «blood vanadium concentration - odds ratio for laboratory abnormalities» relationship models $(p \leq \mathbf{0 . 0 0 0 5})$}

\begin{tabular}{|c|c|c|c|c|c|c|}
\hline \multirow{2}{*}{$\begin{array}{c}\text { Laboratory test (marker } \\
\text { of the effect) }\end{array}$} & \multirow{2}{*}{$\begin{array}{c}\text { Test result } \\
\text { change }\end{array}$} & \multicolumn{2}{|c|}{$\begin{array}{c}\text { Model } \\
\text { parameters }\end{array}$} & \multirow{2}{*}{$\begin{array}{c}\text { Fisher test } \\
\text { (F) }\end{array}$} & $\begin{array}{c}\text { Significance } \\
(\mathrm{p})\end{array}$ & $\begin{array}{c}\text { Coefficient } \\
\text { of determination } \\
(\mathrm{R} 2)\end{array}$ \\
\hline IgG vanadium-specific & Increase & $-1,51$ & 629,1 & 147,77 & 0,000 & 0,78 \\
\hline AsAT & Increase & $-1,06$ & 365,5 & 32,92 & 0,000 & 0,27 \\
\hline IgE total & Increase & $-2,36$ & 786,7 & 188,23 & 0,000 & 0,74 \\
\hline Total protein & Decrease & $-3,36$ & 1050,0 & 724,77 & 0,000 & 0,24 \\
\hline IgA & Decrease & $-2,89$ & 760,5 & 535,15 & 0,000 & 0,58 \\
\hline IgG & Decrease & 1,24 & 243,1 & 137,48 & 0,000 & 0,45 \\
\hline
\end{tabular}

Table 4

Benchmark levels of vanadium in the blood for parameters analysed

\begin{tabular}{|c|c|c|c|}
\hline \multirow{2}{*}{ Laboratory test } & \multirow{2}{*}{ Test result change } & \multicolumn{2}{|c|}{ Confidence limits, $\mathrm{mg} / \mathrm{dm} 3$} \\
\cline { 3 - 4 } & & upper & lower \\
\hline IgG vanadium-specific & Increase & 0,0023 & 0,0026 \\
\hline AsAT & Increase & 0,0026 & 0,0032 \\
\hline IgE total & Increase & 0,0029 & 0,0033 \\
\hline Total protein & Decrease & 0,0031 & 0,0033 \\
\hline Phagocyte count & Decrease & 0,0035 & 0,0040 \\
\hline IgG & Decrease & 0,0039 & 0,0046 \\
\hline IgA & Decrease & 0,0048 & 0,0054 \\
\hline
\end{tabular}

Benchmark vanadium concentration in the blood can be used in solving problems of social and hygienic monitoring, improving the biomonitoring efficiency, performing sanitary and epidemiological expertise of harmful effects on human health under conditions of chronic exposure of vanadium.

The developed complex of highly sensitive mass spectrometric techniques (ICP-MS) allowed estimation of the actual vanadium content in the ambient air at the reference concentration level and determination with high selectivity of the vanadium content in the blood over a wide range of concentrations [14].

\section{References}

1. Bandman A.L., Volkova N.V., Grehova T.D. Vrednye himicheskie veshhestva. Neorganicheskie soedinenija V-VIII grupp: Spravochnoe izdanie [Adverse chemical substances. The group V to VIII inorganic compounds: a reference book]. Ed. V.A. Filova. Leningrad: Himija, 1989. 117 p.

2. Gileva O.V. Metodicheskie priemy kolichestvennogo opredelenija vanadija $\mathrm{v}$ biosredah metodom mass - spektrometrii s induktivno svjazannoj plazmoj [Methodical approaches to quantitative determination of vanadium in biomedia using inductively coupled 
plasma mass spectrometry]. Fundamental'nye $i$ prikladnye aspekty analiza riska zdorov'ju naselenija: materialy Vserossijskoj nauchno-prakticheskoj konferencii molodyh uchenyh $i$ specialistov Rospotrebnadzora. Ed. G.G. Onishhenko, N.V. Zajceva. Perm', 16-18 may 2012, pp. 140-143.

3. Glanc S. Mediko-biologicheskaja statistika [Biomedical statistics]. Ed. N.E. Buzikashvili i soavt. Moscow: Praktika, 1998. 459 s.

4. GN 2.1.6.1338-03. PDK zagrjaznjajushhih veshhestv $\mathrm{v}$ atmosfernom vozduhe naselennyh mest [Environmental Health Standards GN 2.1.6.1338-03. MACs of contaminants in ambient air of populated areas]. Utverzhdeno Glavnym gosudarstvennym sanitarnym vrachom RF 21 maja 2003 g., s izmenenijami ot 3 nojabrja 2005 g., 4 fevralja 2008 g., 27 janvarja 2009 g. Available at: http://snipov.net/c_4819_snip_106868.html.

5. Boev V.M., Boev M.V., Tulina L.M., Neplohov A.A. Determinirovannye jekologicheskie faktory riska dlja zdorov'ja naselenija monogorodov [Determined ecological health risk factors in single factory towns]. Analiz riska zdorov'ju, 2013, no. 2, pp. 39-44.

6. Dolgih O.V., Kevorkov N.N. Osobennosti funkcional'nogo sostojanija immunnoj sistemy v uslovijah vozdejstvija nizkomolekuljarnyh himicheskih soedinenij [Characteristics of the functional condition of the immune system under exposure to low molecular weight chemical compounds]. Medicinskaja immunologija, 2002, vol. 4, no. 3, pp. 473-476.

7. Zajceva N.V., Maj I.V., Klejn S.V. K voprosu ustanovlenija i dokazatel'stva vreda zdorov'ju naselenija pri vyjavlenii nepriemlemogo riska, obuslovlennogo faktorami sredy obitanija [On the determination and proof of damage to human health in the identification of an unacceptable risk caused by environmental factors]. Analiz riska zdorov'ju, 2013, no. 2, pp. 1426.

8. Laboratornye metody issledovanija $\mathrm{v}$ klinike: spravochnik [Laboratory Methods in the clinic: a reference book]. Edit by V.V. Men'shikova. Moscow: Medicina, 1987. 366 p.

9. Lazarev N.V. Vrednye veshhestva v promyshlennosti. Spravochnik dlja himikov, inzhenerov i vrachej.

Neorganicheskie i jelementoorganicheskie soedinenija [Adverse industrial substances. A reference book for chemists, engineers and physicians. Inorganic and organo-elemental compounds]. 7-e izd., pererabotanye i dopolnenye. Leningrad: Himija, 1977, vol. III. 608 p.

10. Metodicheskie rekomendacii «Perechen' prioritetnyh pokazatelej dlja vyjavlenija izmenenij sostojanija zdorov'ja detskogo naselenija pri vrednom vozdejstvii rjada himicheskih faktorov sredy obitanija» ot 19.11.1999. [Methodical guidelines «A list of major indicators to identify health changes in children exposed to adverse environmental chemical factors» dated 19.11.1999]. No. FC/3415. Available at: http://www.businesspravo.ru/Docum/DocumShow DocumID 68761.html.

11. MR 2.1.10.0062-12 2.1.10 Sostojanie zdorov'ja naselenija v svjazi s sostojaniem okruzhajushhej prirodnoj sredy i uslovijami prozhivanija naselenija. Kolichestvennaja ocenka nekancerogennogo riska pri vozdejstvii himicheskih veshhestv na osnove postroenija jevoljucionnyh modelej. Metodicheskie rekomendacii MR [Methodical guidelines MR 2.1.10.0062-12 2.1.10. Population health condition due to natural environmental and dwelling conditions. Quantitative assessment of non-carcinogenic risk of exposure to chemical substances based on building evolutionary models. Methodical guidelines MR]. Moscow: Federal'nyj centr gigieny i jepidemiologii Rospotrebnadzora, 2012. 36 p.

12. MUK 4.1. 2953 - 11. Opredelenie massovoj koncentracii vanadija $\mathrm{v}$ atmosfernom vozduhe metodom mass-spektrometrii $\mathrm{s}$ induktivno-svjazannoj plazmoj [Methodical guidelines MUK 4.1. 2953-11. The determination of the mass concentration of vanadium in ambient air using inductively coupled plasma mass spectrometry]. Utverzhdeno Utverzhdeny Rukovoditelem Federal'noj sluzhby po nadzoru v sfere zashhity prav potrebitelej i blagopoluchija cheloveka Glavnym gosudarstvennym sanitarnym vrachom Rossijskoj Federacii, G.G. Onishhenko. Moscow, 2011. 13 p.

13. Onishhenko G.G., Novikov S.M., Rahmanin Ju.A., Avaliani S.L., Bushtueva K.A. Osnovy ocenki riska dlja zdorov'ja naselenija pri vozdejstvii himicheskih veshhestv, zagrjaznjajushhih okruzhajushhuju sredu [Basics of health risk assessment of exposure to 
chemical substances polluting the environment]. Ed. Ju.A. Rahmanin, G.G. Onishhenko. Moscow: NII JeCh i GOS, 2002. 408 p.

14. Rukovodstvo R 2.1.10.1920-04. Rukovodstvo po ocenke riska dlja zdorov'ja naselenija pri vozdejstvii himicheskih veshhestv, zagrjaznjajushhih okruzhajushhuju sredu [Guidelines R 2.1.10.1920-04. Guidelines for health risk assessment of exposure to chemical substances polluting the environment]. Utverzhdeno 5 marta 2004 g. Glavnym gosudarstvennym sanitarnym vrachom RF. Moscow: Federal'nyj centr gossanjepidnadzora Minzdrava Rossii, 2004. 143 p.

15. SanPiN 2.1.4.1074-01. Pit'evaja voda. Gigienicheskie trebovanija k kachestvu vody centralizovannyh sistem pit'evogo vodosnabzhenija. Kontrol' kachestva [SanPin 2.1.4.1074-01. «Drinking water. Hygiene standards for drinking water quality in centralized drinking water supply systems. Quality control»]. Utverzhdeno Glavnym gosudarstvennym sanitarnym vrachom Rossijskoj Federacii 26 sentjabrja 2001 g. Available at: http://www.etch.ru/norma.php?art=2.

16. Jekologicheskij doklad «Sostojanie i ohrana okruzhajushhej sredy Permskogo kraja v 2012 godu» [Ecological report «Environment condition and protection in the Perm Region in 2012»]. Upravlenie po ohrane okruzhajushhej sredy Ministerstva prirodnyh resursov Permskogo kraja. Available at: http://www.permecology.ru/reports2012.php.

17. Tic N. Klinicheskoe rukovodstvo po laboratornym testam [Clinical guidelines for laboratory testing]. Moscow: JuNIMED-press, 2003. 960 p.

18. Fletcher R., Fletcher S., Vagner Je. Klinicheskaja jepidemiologija. Osno-vy dokazatel'noj mediciny 1998. $352 \mathrm{p}$.

[Clinical Epidemiology. You based evidence-based medicine]. Moscow: Media Sfera,

19. Draft Toxicology Profile for Vanadium. U.S. Department of Health and Human Services. Public Health Service Agency for Toxic Substances and Disease Registry, 2012, September. $255 \mathrm{p}$.

20. Screening Assessment for the Challenge. Vanadium oxide (Vanadium pentoxide). Environment Canada. Health Canada, 2010, September. 100 p. 